\title{
Cigarette smoke exposure induced animal models of COPD - procedural variations and apparatus
}

\author{
Urmila Manoj Aswar ${ }^{1, A-B, D-F \oplus}$, Deepti Rai ${ }^{1, A-E \oplus}$, Farheen Siddiqui ${ }^{1, A-B, D \oplus}$, \\ Subhash Laxmanrao Bodhankar ${ }^{1, \mathrm{E}-\mathrm{F} \oplus}{ }^{\oplus}$, Prasad Thakurdesai ${ }^{2, \mathrm{E}-\mathrm{F} \odot}$ \\ ${ }^{1}$ Department of Pharmacology, Poona College of Pharmacy, Bharati Vidyapeeth University, Erandwane, India \\ ${ }^{2}$ Indus Biotech Pvt Ltd., India \\ A - Research concept and design, B - Collection and/or assembly of data, C - Data analysis and interpretation, \\ $D$ - Writing the article, E - Critical revision of the article, F- Final approval of the article
}

Urmila Manoj Aswar, Deepti Rai, Farheen Siddiqui, Subhash Laxmanrao Bodhankar, Prasad Thakurdesai. The Cigarette Smoke Exposure Induced Animal Models of COPD: Procedural Variations and Apparatus. J Pre-Clin Clin Res. 2021; 15(4): 184-191. doi: 10.26444/jpccr/143005

\begin{abstract}
Introduction and objective. Chronic obstructive pulmonary disease (COPD) is a progressive disorder that makes breathing difficult, characterized by chronic bronchitis, mucus hypersecretion, airway remodelling, and emphysema. Although caused by various factors, the leading cause is active or passive cigarette smoking (CS). The treatment available provides symptomatic relief and is associated with serious adverse effects, such as cardiovascular events and pneumonia; hence, there is an unmet need for research on drug treatment for COPD. This literature review provides an update on the various animal models of COPD that have been developed by the exposure of CS alone, or in combination with other inducing agents.

Abbreviated description of the state of knowledge. The combination of SCS/MCS with LPS should be preferred to a single smoke component to induce COPD. It was observed that mouse models are extensively used, C57B1/6 and BALB/c females are more vulnerable to COPD, whereas, in rat models, male SD rats are mostly used. Guinea pigs, due to their anatomical similarity, are found to be a better model that can be used to develop COPD.

Conclusions. Suitable animal models and validated apparatus are crucial for successful COPD animal model development. Conventionally authenticated research-grade cigarettes should be used for effortless distribution of a specific concentration of total suspended particles (TSP) or total particulate matter (TPM), including nicotine and carbon monoxide. There is also a need to focus on the various types of apparatus to be used for COPD induction in murine models considering optimum exposure, reliability as well as the sturdiness of the apparatus which would provide better execution of the protocol with minimum harm to the experimenter.
\end{abstract}

\section{Key words}

rat, cigarette smoke, COPD, emphysema, mainstream cigarette smoke, apparatus

\section{INTRODUCTION}

Chronic obstructive pulmonary disease (COPD) is a progressive disorder characterized by difficulty in breathing, chronic airway inflammation, mucus hypersecretion, airway remodelling, chronic bronchitis, and emphysema. It has become a leading cause of respiratory-related illness and mortality. The Global Initiative for Chronic Obstructive Lung Disease (GOLD) has predicted that COPD will become the third most leading cause of death worldwide in the coming years. The disease can have many underlying reasons, such as active cigarette smoking, breathing polluted air, or genetic conditions like alpha -1 antitrypsin deficiency (AAT). The emphasis, however, is more on CS as it is the prime source of COPD. The underlying mechanism of CS-induced COPD is an invasion of inflammatory cells, which induces thickening of the bronchial walls [1], imbalances between protease- antiprotease $[2,3]$ and oxidant-antioxidant [4] hypothesis have

Address for correspondence: Urmila Manoj Aswar, Department of Pharmacology, Poona College of Pharmacy, Bharati Vidyapeeth Deemed to be University, Erandwane, Paud Rd, Rambaug Colony, Erandwane, Pune, Maharash, 411038 Pune, India

E-mail: aswarurmila@gmail.com

Received: 08.07.2021; accepted: 11.10.2021; first published: 19.10.2021 also been accepted. Figure 1 depicts the pathophysiology of COPD. Smoking activates alveolar macrophages, which, with the help of chemoattractants-CXCR2 (CXC chemokine receptor 2) and CXCL1 (CXC ligand 1) result in the infiltration of neutrophils, monocytes, and CD8+ T lymphocytes. The neutrophils ultimately cause activation of proteases (serine proteases, matrix metalloproteinase, and cysteine proteases) that result in the destruction of connective tissue and alveolar cells in the lung, and mucus hypersecretion thereby inducing emphysema. CD8+ T-cells also lead to alveolar wall destruction by activating the apoptosis pathway. The reactive oxygen species (ROS) cause oxidative stress which inactivates the anti-proteases. tissue inhibitor of matrix metalloproteinase and decreases the levels of VEGF (Vascular endothelial growth factors) that also leads to apoptotic destruction of the alveolar walls and causing COPD.

COPD is confirmed using a spirometry test where the ratio of forced expiratory volume (FEV) in 1 s and forced vital capacity $(\mathrm{FVC})$ is less than $0.7(\mathrm{FEV} 1 / \mathrm{FVC}<0.7)[5,6], \mathrm{AAT}$ deficiency screening $[7,8]$ is performed to ensure relation with a genetic cause. The primary treatment for the disease would be a lifestyle change, an initiative for which should be cessation of smoking. Since COPD is a long-term process and progressive disorder, consequently, if the occurrence of 


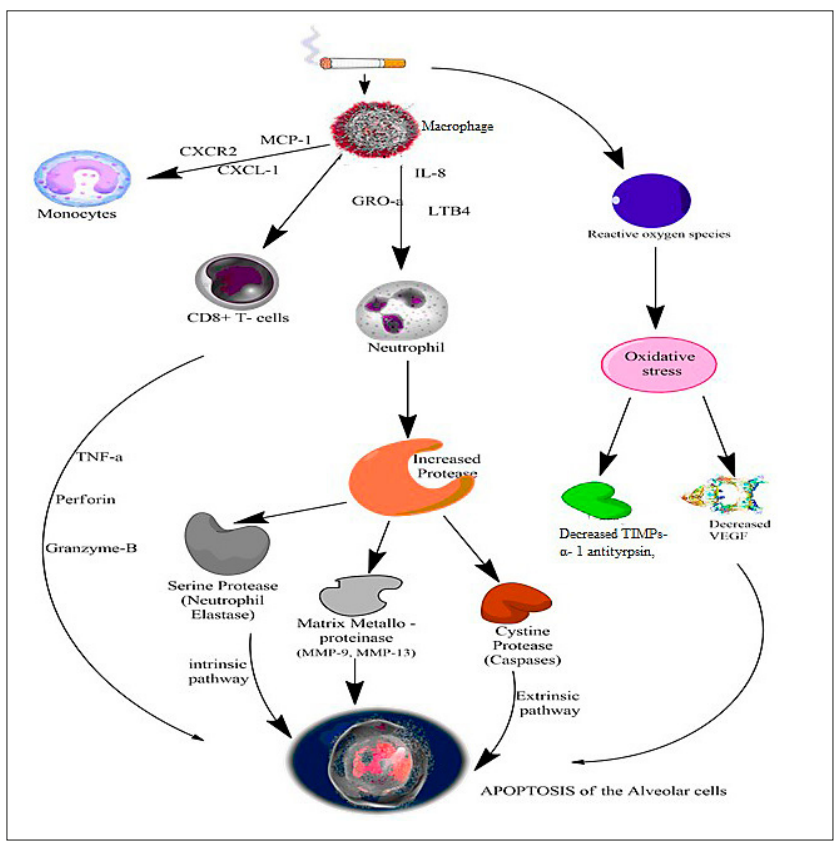

Figure 1. Pathophysiology of COPD due to CS: CS activates alveolar macrophages which with the help of release chemoattractants summons neutrophils, monocytes and CD8+Tlymphocytes. The neutrophils ultimately cause activation of proteases (Serine proteases, Matrix metalloproteinase, Cysteine proteases), which cause emphysema and mucus hypersecretion due to apoptosis of the alveolar cells. CD8+ T-cells also lead to alveolar wall destruction by activating the apoptosis pathway. The ROS causes oxidative stress which inactivates the anti-proteases (tissue inhibitor of matrix metalloproteinase-TIMP) and decrease the levels of VEGF resulting in the apoptotic destruction of the alveolar walls. MCP-1: Monocytes Chemoattractants Protein-1, GRO a: Growth related oncogenes- $a$, CXCR2: C-X-C chemokine receptor (Interleukin- 8 receptor gene), LTB4- Leukotriene B4, CXCL-1: C-X-C ligand-1, ROS: reactive oxygen species, VEGF: Vascular endothelial growth factors

the disease is slow, so is the cure. There has been very little improvement regarding new therapies for COPD treatment, which includes long-acting bronchodilators [9]. Instead of being devoid of the effectiveness of current medicine in ameliorating the long-term decline in lung function [9, $10]$, there is a lack of research interest in understanding the molecular biology of COPD that may be attributed to inefficient animal models for testing newer drug molecules, and dearth of an accurate and reliable model which can replicate the disease in humans.

Different animal models for COPD induction. The method of induction includes CS exposure, lipopolysaccharide (LPS) instillation, respiratory infections (RI), and genetic modifications. CS acts by triggering the fibrogenic growth factors (TNF- $\alpha$ etc.) in the walls of the airways, creating a small airway remodeling. This is the most common etiological consideration [11]. LPS evokes the inflammatory stimulus and causes chronic bronchitis. LPS, a TOLL-like receptor-4 (TLR-413 ligand, stimulates the p38 mitogenactivated protein kinase (MAPK) intracellular signalling, which further increases the production of pro-inflammatory cytokines thereby activating the NF-kB transcription factor $[12,13]$. Proteolytic enzymes like elastase are also used for the induction of COPD by the manifestation of emphysema. These proteolytic enzymes are released from the activated neutrophils in the lungs and are responsible for the breakdown of the parenchymal matrix, specifically by degrading elastin. The models developed by the instillation of elastics are generally termed 'elastase emphysema' [14]. This model also supports the hypothesis of protease-antiprotease imbalance in COPD. RI is generally developed in combination with CS or LPS, as they are responsible for the exacerbation seen in COPD patients. The RI aggravates the condition and makes it fatal for the patients. Hence, the respiratory infection-induced animal models are superior and best suited for COPD exacerbation conditions. Genetically COPD can occur due to abnormal alterations or the absence of specific genes such as AAT [15]. Many genetically modified mice show over-expression of collagenase 1 (MMP-1), IL-13, IFN- $\gamma$ [16]. Some mice that are naturally mutated, such as Tsk mice, have a mutation in the fibrilin-1, a matrix protein [17]. Similarly, pallid, blotchy, and beige mice, which are naturally mutated, can be used as a genetic model in COPD. The various animals such as guinea pigs, rats, and mice in conjunction with several inducing methods are used. Mice and the rats have smaller branches of the bronchi compared to humans, and also have a highly extensive bronchial tree, which is the main organ affected by smoke exposure resulting in airway remodelling. Humans exhibit ciliated cells of the epithelium, as well as goblet cells, which are umpteen in the large airways, and has a similarity with that of guinea pigs, whereas in rats and mice the bronchial tree is non-ciliated [18]. In humans, the bronchial glands, consisting of mucus and serous cells that are abundantly found in the airways, and hypersecretion of mucus, is a major contributory factor for COPD. Conversely, these glands are limited only to the upper tracheal portion in rats, absent in mice, and are non-uniformly distributed in the guinea pig [19]. These findings suggest that guinea pigs exhibit advantages over the models of rats and mice.

CS-induced COPD induction. CS plays a crucial part in the development of COPD, lung cancer, asthma, and many more respiratory-related disorders. CS consists of more than 4,000 definite compounds, including tar, nicotine, acrolein, ammonia, etc. [20]. The International Agency for Research on Cancer (IARC) specified that 9 out of the 44 chemical agents classified as the 'Group I carcinogens', reside in the MCS [21]. The classic animal model for any disease is that symptoms observed in animals must mimic the disease in the humans. Previous work has demonstrated development of COPD in various animal species, such as rats, mice, monkeys, sheep, dogs, guinea pigs [22], instead of their deviation from human physiology. Therefore, the challenge is the selection of the right animal model for induction of COPD, the use of correct apparatus with validated CS exposure, the number of cigarettes, and the duration of the exposure. The present review discusses various animal models used for the induction of COPD with their advantages and disadvantages. These models are classified based on the various ways of smoke exposure and also on the type of animal used.

\section{LABORATORY ANIMAL MODELS FOR INDUCING COPD USING DIFFERENT WAYS OF CS EXPOSURE}

Use of sidestream CS (SCS) for inducing COPD. Many studies have reported that passive smoking is equally or even more harmful compared to active smoking, with a 50 times higher possibility of accumulating toxic chemicals in the body than active smokers [23]. Passive smoking produces higher particulate matter pollution, which contains the gas phase and combustion products of CS which may deteriorate 
the respiratory system [24]. The SCS model represented the early and advanced stages of COPD using short-, middle-, and long-term SCS (non-filtered containing $25 \mathrm{mg}$ tar and $1.4 \mathrm{mg}$ nicotine per cigarette) exposure. Groups were tested according to the week of CS exposure, for $2,4,8,12,24$, and 36 weeks. The parameters tested were weight loss, open field test (patients become depressed and anxious as COPD advances ultimately moving lesser to circumvent the discomfort), lung function tests, cytokines estimation in serum and bronchoalveolar lavage fluid (BALF), estimation of lung tissue protein levels and analysis of blood gases (advanced stage COPD shows hypercarbia, hypoxemia, and an acid-base imbalance). An SCS exposure for 24 weeks, induces moderate and 36 weeks, cause advanced stage COPD pathogenesis. COPD takes time to develop in humans, establishing animal models that show the gradual progress of COPD to understand the various stages of the disease is hence needed [25-27]. Following study used SCS for inducing COPD in male Wistar rats. The exposure was for $2,4,6,8,10,12,24$, and 36 weeks in the CS chamber, where the concentration of carbon monoxide was maintained at $231 \pm 11 \mathrm{ppm}$. The analyzed parameters were lung function test using the forced oscillation technique, pathological changes using histological analysis, and mucin measurement. Pathological changes obtained from 36 weeks of exposure showed the characteristic features of COPD, such as small airway remodelling, tissue oedema, thickening of the epithelial layer of the lumen, indicating that these models will be useful for studying CS-induced COPD and confirm the relationship between passive smoking and COPD [28].

An animal model consisting of male SD rats were exposed to SCS $(8 \mathrm{mg}$ tar, $0.8 \mathrm{mg}$ nicotine, and $10 \mathrm{mg}$ carbon monoxide) in a special smoking chamber supplied with oxygen. The BALF and tissue collected revealed the exposure to CS has shown prominent accumulation of neutrophils and macrophages and significant damage of the alveolar walls along with the pathological feature of airway tissue remodelling, increased expression of $\mathrm{mRNA}$ and protein level of MMP-8, 9, 12 [29]. Similarly, a 3-month study has also been performed on C57B16/J mice where SCS exposure was generated by a smoking machine where smoke was produced and standardized for $35 \mathrm{ml}$ puffs by burning ( $48 \mathrm{~h}$ in $60 \%$ humidity) cigarettes (Kentucky 2R4F reference cigarette). Every minute, a total of 8 puffs (for $2 \mathrm{~s}$ ) was given once, after every $58 \mathrm{~s}$ with a 2 puff of mainstream smoke, side-stream smoke was reinforced to duplicate second-hand smoke (SHS). There were 2 chambers arranged in a series, from which generated smoke was passed. Initially, a high dose SHS and medium-dose SHS were administered ( ${ }^{\text {st }}$ month); thereafter, a high dose of SHS exposure was given. At the $6^{\text {th }}$ week, the high dose of SHS was increased to $150 \mathrm{mg} / \mathrm{m}^{3}$ of total suspended particular (TSP) matter. Carbon monoxide was monitored with a model 880 non-dispersive-infrared (NDIR) analyzer (Beckmann Industries, La Habra CA, USA), and nicotine concentration was determined by gas chromatography. It was found that there was an increase in alveolar macrophage recruitment, the protein level of inflammatory mediators CCL2 and tumour necrosis factor (TNF- $\alpha$ ), PLA2g7 (a highly produced gene in human smokers) in BALF. Hence, shortterm exposure and expression of markers were found to be similar to the habitual human smoker $[30,31]$.

Use of SCS along with LPS for inducing COPD. LPS has the ability to induce a short term model of COPD with more relevance to COPD in a clinical setup [32]. LPS is the outer wall constituent of gram-negative bacteria and also presents as a contaminant of tobacco smoke, organic dust, and environmental pollution [33]. It can induce COPD exacerbations of acute type, alone or in combination with CS. Its exposure can stimulate inflammatory responses when given for 12 weeks (twice weekly) [34]. Some studies have shown that the combination of LPS along with the SCS reduces the induction time. Li et al. (2017) [35] induced by passive CS (tar yield $11 \mathrm{mg} /$ cigarette, nicotine $0.8 \mathrm{mg} /$ cigarette, CO yield $13 \mathrm{mg} /$ cigarette) and LPS (endotracheal intubation of $200 \mu \mathrm{l}$ ) on days 1 and 14 . They found exposure to CSinduced emphysema in rats, as observed by the increase in bronchiole wall thickness, small pulmonary vessel wall thickness, bronchial stenosis, and alveolar diameter. They reported significant oxidative stress as determined from the ratio of GSH/GSSG (Glutathione/ Glutathione disulfide), 8-OHdG (8-hydroxydeoxyguanosine), and 4-HNE (4-Hydroxynonenal implicated the role of the ERK/Nrf2 signalling pathway in COPD. Certain studies emphasize, glucocorticoid resistance in COPD. They exposed the whole rats to SCS (tar content $13 \mathrm{mg}$, and the nicotine content $0.8 \mathrm{mg}$ ) for 28 days in a custom-built fumigation chamber of $72 \mathrm{~L}$, with an intratracheal injection of LPS on the $1^{\text {st }}$ and $14^{\text {th }}$ day. They found increased levels of 8-iso-PGF2 $\alpha$, interleukin8 (IL-8), and TNF- $\alpha$ in BALF and serum, while a decreased expression level of HDAC2 (histone deacetylase subtype plays a major role in preventing pathogenesis by inhibiting the expression of an inflammatory gene), and increased levels of PI3K, and p-AKT (oxidative stress activates this pathway which ultimately causes phosphorylation and inactivation of HDAC2) in lung tissue [36, 37]. Male, Dunkin Hartley out-bred guinea pigs $(350-400 \mathrm{~g})$ were used in a study for the induction of COPD using $200 \mu \mathrm{L}$ LPS intranasal instillation $(5 \mathrm{mg} / \mathrm{ml}$ in sterile saline). After scarification sacrifing the animals, the lungs were retrieved and used for measuring various parameters for confirmation of the disease. MUC5AC or smooth muscle myosin heavy chain (sm-MHC) for analyzing smooth muscle and goblet cells, identification and counting of the neutrophils of the airways, hydroxyproline estimation to assess the collagen content for airway fibrosis (increased by 1.3 -fold). Moreover, emphysema was characterized by the calculation of Mean Linear Intercept (MLI) which was increased by $7.3 \%$. All these parameters indicated the successful induction of disease and the proper development of the model for COPD.

Use of mainstream CS (MCS) with LPS for inducing COPD. COPD in humans is caused by CS exposure, but CS-induced COPD is a long-term process in humans as well as animals. To develop the disease, the experimental designs are modified with combinations of various COPD-inducing agents such as CS+LPS. Studies have reported that LPS is an active component of CS [32] and is capable of activating innate immunity $[13,38]$. Hence, a combination of MCS along with LPS can be a useful animal model for COPDrelated studies. A study was conducted to compare 3 rat models of COPD induced by CS exposure alone or combined with pre-or post-treatment with LPS. The male SD rats were exposed to CS (12 mg tar and $1.2 \mathrm{mg}$ nicotine per cigarette) (Tab. 1). Only the CS group received CS for 40 days, whereas LPS $(200 \mu \mathrm{g} / \mathrm{kg}, 20 \mu \mathrm{g} / \mathrm{ml}$ dissolved in saline, intratracheal) treatment, in LPS+CS ( $1^{\text {st }}$ day, $1 \mathrm{~h}$ before CS exposure $)$ and 
Table 1. Different ways of CS exposure and induction of COPD in laboratory animals

\begin{tabular}{|c|c|c|c|c|}
\hline Inducting agent & Animals & Method & Comment & Reference \\
\hline \multirow[t]{3}{*}{ Sidestream CS } & \multirow[t]{2}{*}{ Rat } & $\begin{array}{l}\text { 1) CS exposure started with } 2 \text { cigarettes a day and increased } \\
\text { gradually to } 6 \text { cigarettes per day ( } 3 \text { cigarettes morning and } \\
\text { evening), } 15 \mathrm{~m} \text { / cigarettes, with interval of } 5 \mathrm{~m} \text {. }\end{array}$ & $\begin{array}{l}4 \text { weeks exposure showed coughing and sneezing. At } 24 \\
\text { weeks, the animal exhibited declined trend in the body } \\
\text { weight and at } 36 \text { week they showed significant reduction in } \\
\text { body weight. }\end{array}$ & {$[26,27]$} \\
\hline & & $\begin{array}{l}\text { 2) Twenty cigarettes per day for } 1 \mathrm{~h} \text { twice a day, } 5 \text { days a } \\
\text { week up to } 16 \text { weeks. }\end{array}$ & $\begin{array}{l}\text { Early stage of the animals showed anxiety, whereas late } \\
\text { stage showed shrivelled hair, yellowing of the teeth and less } \\
\text { movement and after } 16 \text { weeks significant weight loss was } \\
\text { observed. }\end{array}$ & {$[28]$} \\
\hline & Mice & $\begin{array}{l}\text { 8-week-old mice were exposed to sidestream cigarette in the } \\
\text { form of puffs (total } 8 \text { puffs), } 5 \text { day per week, } 6 \mathrm{~h} \text { per day. }\end{array}$ & $\begin{array}{l}\text { 3-week exposure to sidestream smoke to mice showed } \\
\text { increased expression of certain alveolar macrophage genes } \\
\text { and increased protein levels of inflammatory mediators CCL2 } \\
\text { and TNF-a in BALF. }\end{array}$ & {$[30,31]$} \\
\hline \multirow[t]{2}{*}{ SCS and LPS } & \multirow[t]{2}{*}{ Rat } & $\begin{array}{l}\text { 1) } 10 \text { cigarettes per day, } 1 \mathrm{~h}(10 \mathrm{~m} \text { interval post } 30 \mathrm{~m}) \text { twice } \\
\text { a day for } 12 \text { weeks, LPS was also administered on days } 1 \text { and } \\
14 .\end{array}$ & $\begin{array}{l}\text { Exposure to CS and LPS induced emphysema and increase in } \\
\text { alveolar diameter. }\end{array}$ & {$[35]$} \\
\hline & & $\begin{array}{l}\text { 2) } 1 \text { cigarette/rat exposure lasting half hour for each } \\
\text { exposure, twice a day, at an interval of at least } 6 \mathrm{~h} \text {. }\end{array}$ & $\begin{array}{l}\text { Significant increase in the inflammatory cytokines along } \\
\text { with bronchial smooth muscle thickening, inflammatory cell } \\
\text { infiltration and alveolar wall rupture was also seen. But due } \\
\text { to short modelling time, partial COPD characteristics were } \\
\text { established. }\end{array}$ & {$[36,37]$} \\
\hline \multirow[t]{2}{*}{$\begin{array}{l}\text { Mainstream CS } \\
\text { and LPS }\end{array}$} & Rat & $\begin{array}{l}24 \text { cigarettes per day } 1 \mathrm{~h} \text { twice a day, } 7 \text { days a week, CS } \\
(6 \text { week), LPS+CS ( } 4 \text { week), CS+LPS ( } 6 \text { week). }\end{array}$ & $\begin{array}{l}\text { The airway inflammation, emphysema, and mucous plugging } \\
\text { in small bronchioles were more severe in the animals of CS + } \\
\text { LPS group as compared to that in CS and LPS + CS groups. }\end{array}$ & {$[37,38]$} \\
\hline & Mice & $\begin{array}{l}\text { Mainstream CS at } 250 \mu \mathrm{g} / \mathrm{L} \text { wet total particulate matter } \\
\text { (WTPM) for } 5 \mathrm{~h}, 0.5 \mu \mathrm{g} \text { LPS/L for } 1 \mathrm{~h} / \text { day, twice per week, } \\
\text { Smoke group }(250 \mu \mathrm{g} / \mathrm{L}, \mathrm{WTPM}), \mathrm{LPS} \text { group }(0.5 \mu \mathrm{gLPS} / \mathrm{L}) \text {, } \\
\text { Smoke + LPS group }(250 \mu \mathrm{g} / \mathrm{L}, \mathrm{WTPM}+0.5 \mu \mathrm{g} \text { LPS/L). }\end{array}$ & $\begin{array}{l}\text { Combine exposure of smoke and LPS results in different gene } \\
\text { expressions of muscle contraction and ROS, which is relevant } \\
\text { in COPD. }\end{array}$ & {$[41]$} \\
\hline \multirow[t]{2}{*}{$\begin{array}{l}\text { Mainstream CS } \\
\text { and respiratory } \\
\text { infection }\end{array}$} & Rat & $\begin{array}{l}\text { CS exposure- } 15 \text { cigarettes per day each time, thrice a day, } \\
30 \text { m exposure with } 3 \mathrm{~h} \text { interval between each exposure. for } \\
12 \text { weeks } \\
\text { Bacterial infection: Klebsiella pneumoniae dilution }(6 \times 108 \\
\text { CFU } / \mathrm{mL}, 0.1 \mathrm{~mL} \text { ), intranasal, once a day, } 5 \text { days a week for } 8 \\
\text { weeks. }\end{array}$ & $\begin{array}{l}\text { Changes in pulmonary function such as reduction in VT, PEF } \\
\text { and EF50, as well as emphysema and small airway remodelling } \\
\text { was seen. Even after the exposure had stopped the animals } \\
\text { were under observation for } 6 \text { months and results showed } \\
\text { establishment of stable COPD. }\end{array}$ & {$[15]$} \\
\hline & Mice & $\begin{array}{l}4 \mathrm{~h} \text { a day, } 5 \text { days per week, for } 6 \text { months, RSV was } \\
\text { administered intranasal with a dose of } 1 \times 10^{6} \mathrm{pfu} \text {. }\end{array}$ & $\begin{array}{l}\text { The CS exposed mice lost body weight gradually which were } \\
\text { accelerated due to the administration of RSV. Apoptosis, } \\
\text { inflammatory and proteolytic responses were aggravated. }\end{array}$ & {$[46]$} \\
\hline \multirow[t]{4}{*}{$\begin{array}{l}\text { Mainstream CS } \\
\text { (Active) }\end{array}$} & \multirow[t]{2}{*}{ Rat } & $\begin{array}{l}\text { 1) } 12 \text { commercial filter cigarette per day ( } 4 \text { each time), thrice } \\
\text { a day, for } 1 \mathrm{~h} \text { each time, during } 1 \mathrm{~h} \text { exposure after every } 15 \mathrm{~m} \\
\text { a pause of } 5 \mathrm{~m} \text { was given. }\end{array}$ & $\begin{array}{l}\text { Weight loss was seen in the disease group and results show } \\
\text { development of emphysema in the rats. }\end{array}$ & {$[47]$} \\
\hline & & $\begin{array}{l}\text { 2) } 20 \text { cigarette, } 2 \text { h exposure, twice daily, with } 4 \text { h gap in } \\
\text { between for } 6 \text { days a week up till } 28 \text { weeks. }\end{array}$ & $\begin{array}{l}\text { Irreversible loss of normal lung function, airway congestion, } \\
\text { epithelial necrosis erosion, smooth muscle proliferation, } \\
\text { numerous inflammatory cells in the alveolar walls and spaces, } \\
\text { small airway fibrosis and massive disruption of lung structure } \\
\text { was observed. }\end{array}$ & {$[48,49]$} \\
\hline & Mice & $\begin{array}{l}5 \text { cigarettes, } 5 \text { days a week for } 8 \text { weeks, } 4 \text { times a day, with } 10 \\
\text { m interval in between. }\end{array}$ & $\begin{array}{l}\text { Increased level of proinflammatory cytokines (TNF-a, IL-1 } \beta \text {, } \\
\text { IL-6) were observed, significant injury in the epithelial cells } \\
\text { of bronchi, metaplasia of goblet epithelium cells, mucus } \\
\text { secretion was also seen. }\end{array}$ & {$[50,51]$} \\
\hline & $\begin{array}{l}\text { Guinea } \\
\text { Pig }\end{array}$ & $\begin{array}{l}7 \text { cigarettes, } 5 \text { days per week, for } 2,4 \text { and } 6 \text { months, only } \\
\text { nose was exposed. }\end{array}$ & $\begin{array}{l}\text { Prominent body weight decline was demonstrated though } \\
\text { the oxidative stress was not very significant. }\end{array}$ & {$[51]$} \\
\hline
\end{tabular}

Abbreviations: CS - Cigarette smoke; SCS - sidestream cigarette smoke; LPS - lipopolysaccharide; RSV - respiratory syncytial virus; VT - tidal volume; PEF - peak expiratory flow; EF50 - Expiratory flow at $50 \%$ of forced vital cepacity; $\mathrm{m}$ - minute; $\mathrm{h}$ - hour

CS+ LPS (39 $9^{\text {th }}$ day, $1 \mathrm{~h}$ before the last CS) groups, along with CS. The number of cigarettes was increased gradually to 12 cigarettes for each exposure. The study showed serious airway inflammation, emphysema, and mucous plugging in small bronchioles in the CS + LPS group animals, compared to that in the CS group. However, the LPS+CS group showed minor changes - goblet cell metaplasia, and increased expression of mRNA of MUC5AC and MUC5B. Lung total protein was used to determine NF-kB p65 (c-p65), cytoplasmic AP-1 (cAP-1), cytoplasmic HDAC2 (c-HDAC2), TLR4, and EGFR tyrosine kinase signalling cascades. Nuclear protein was used for investigating the nuclear NF-kB p65 (n-p65), nuclear AP-1 (n-AP-1), and nuclear HDAC2 (n-HDAC2). All these parameters indicated the development of COPD. Thus, it can be corroborated that compared to pre-treatment with LPS, post-treatment with it aggravated the disease progression [39-41]. Another study used a 3-week exposure of MCS (2R4F reference cigarette, aerosol- $0.61 \mu \mathrm{m}$ mass median aerodynamic diameter (MMAD) with LPS (aerosol-0.34$0.58 \mu \mathrm{m}$ (MMAD) administration) into the mice (Tab. 1). The CS and LPS were administered separately (Smoke group, and LPS group) and in combination (Smoke + LPS group). 


\section{A: MAINSTREAM SMOKE EXTRACTION}

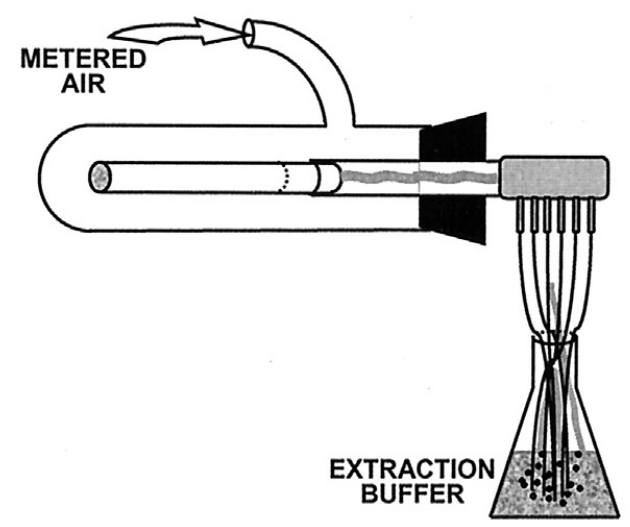

\section{B: SIDESTREAM SMOKE EXTRACTION}

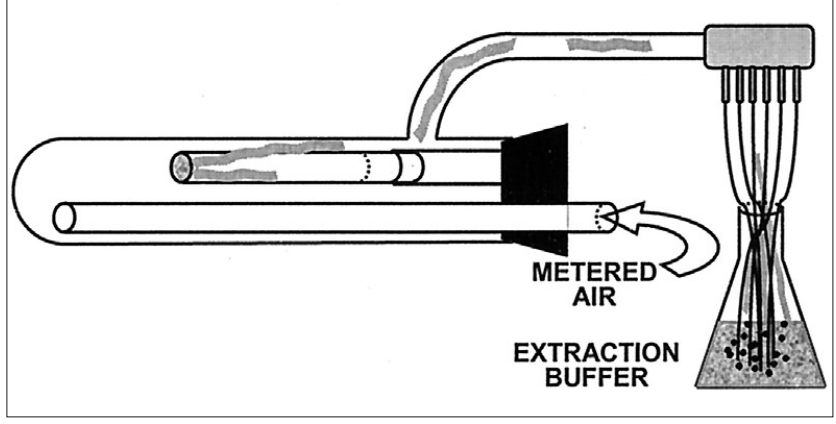

Figure 2. Difference of Mainstream and Sidestream cigarette smoke exposure

A nose-only exposure to smoke was given to the animals using the CS machine Borgwaldt-KC condor Sm85. The study indicated that changes in gene expression generally occurred in the early stage of the disease and can be used to predict disease outcome and mechanism. There was decreased chaperone (heat shock protein) activity, increased inflammatory response, immune response, and mitosis. Respiratory function parameter was estimated using a plethysmograph (Buxco system) and digitized respiratory flow, which measured tidal volume [TV], respiratory rate $[\mathrm{RR}]$, and minute volume [MV]. The differentially expressed genes in the combination group of CS+LPS were altered more significant than in the other groups. Furthermore, the use of 'Clustering', a data-oriented gene expression analysis that provides an accurate description of gene groups that are coregulated, was carried out. The mechanism was deduced by Metacore software signature networks which provides more detailed and convincing evidence of changes in biological processes of chemical or biological problem. The study concluded that the combination of CS and LPS can give a better animal model for COPD induction, and also that there is a need for better and enhanced methods of detection and analysis to confirm the disease $[42,43]$.

Use of MCS with RI for inducing COPD. RI, like bacterial and viral infections, has been implicated in COPD pathogenesis, and the viruses are a significant cause of COPD exacerbations [44]. Along with CS, viral and bacterial infections are major risk factors in COPD. They have been used as animal models for the induction of COPD, alone or in combination [45].
In a study of male and female SD, rats were subjected to repetitive bacterial infection (Klebsiella pneumoniae dilution) for 8 weeks, along with whole-body CS (tobacco, tar: $14 \mathrm{mg}$, nicotine content: $1.2 \mathrm{mg}$, carbon monoxide: $15 \mathrm{mg}$ ) exposure for 12 weeks (Tab. 1). The COPD was found to be developed using the whole-body plethysmograph, BALF, and serum analysis along with histopathological examination. The lung function of the animals began to decline from the $8^{\text {th }}$ week and continued to decline until the $32^{\text {nd }}$ week. The inflammatory cytokines, TNF- $\alpha$, IL-8, IL-10 in BALF as well as serum were found to be markedly increased, and histopathological analyses showed airway remodeling, obstruction, and emphysema. Considering that respiratory problems can occur due to bacterial or viral infection, along with CS, the study ascertains that the combination group to a large extent mimics human COPD [15]. Another experiment demonstrated COPD in mice when a combination of CS and respiratory syncytial virus (RSV) infection was used. The study used C57BL/6J mice (12-week) for 6-months of CS exposure in which RSV infection was initiated at 2 weeks post initiation of CS exposure, and was continued for 6 months. The study indicated that RSV infection exacerbated apoptosis and increased inflammatory and proteolytic responses, which were further triggered by CS exposure. These results concluded that preventing and treating RSV infection would contribute to COPD drug development [46].

Use of MCS for inducing COPD. There are many animals models developed based solely on exposure to mainstream CS. Most importantly, exposure to the active kind of smoke of cigarette is possible only if an appropriate apparatus is used. Rodrigo et al. (2014) [47], demonstrated the development of a new model of CS-induced emphysema in rats. Exposure of CS (0.8 mg of nicotine, $10 \mathrm{mg}$ of tar, and $10 \mathrm{mg}$ of carbon monoxide) to the male Wistar rats every day for 30 weeks, the rats developed COPD, as observed by respiratory parameters, lung function tests, and histopathology of the lungs. It was observed that the airway resistance (Raw), respiratory system resistance, respiratory system compliance (Crs), tissue damping, and tissue elastance were higher in the diseased group compared to the control group, suggesting airspace enlargement, supported also by histopathology. The results of that study correlate well with most of the patients with COPD who smoked cigarettes. Another study performed by Ke et al. (2020) [48], used male SD rats, which were subjected to 28 weeks of whole-body CS exposure (1R1; Derby Cigarettes, tar-10 mg, cotinine- $0.9 \mathrm{mg}$, CO- $12 \mathrm{mg}$ per cigarette,). The apparatus used for exposure was the BUXCO animal CS-exposure system (DSI, USA) which can provide CS equivalent to 20 cigarettes (Tab. 1). Various parameters were conducted to assess the disease, such as lung function, which showed decreased peak expiratory flow (PEF) and a maximal mid-expiratory flow curve (MMF); bioassay of the trachea revealed a significant decrease in contractility, and serum analysis for cytokine indicated an increase in the inflammatory cytokines, such as IL$1 \beta$, IL-8, IL-33, TNF- $\alpha$. Immunohistochemical analysis demonstrated increased expression of $\alpha$-smooth muscle actin, whereas histopathological examination of the lungs showed congestion of the airways, epithelial necrosis erosion, and proliferation of smooth muscle cells [49]. In another study, using male ICR mice exposed with CS (Reference 3R4F without filter, University of Kentucky, Lexington, KY, 
USA; smoke/air ratio of $1 / 6$ ) for 8 weeks (Tab. 1), there was an increase in MDA level and a decrease in SOD level, as well as increased TNF- $\alpha$, and IL-1 $\beta$. Lung histopathology indicated inflammatory infiltration in the alveolar and bronchial walls. However, this was not a continuous exposure and the model may not mimic human COPD [50]. Another study utilized exposure of CS (11mg tar, and $0.8 \mathrm{mg}$ nicotine) to male Hartley guinea pigs (300g). The animals were exposed to the CS for 2, 4, and 6 months with a nose-only inhalation system (Tab. 1). The smoke exposure was validated using the HbCO (carboxyhemoglobin) in the blood and was found to be higher post-exposure. There was a reduction in GSH and high ROS in mitochondria of skeletal muscles, high serum and lung TNF- $\alpha$ level with a concomitant reduction in body weight. Hence, 6-month exposure to a nose-only CS study can be considered as a reliable model of COPD mimicking clinical disease. However, a 5 days per week exposure becomes a limitation when considering the smoking habit in humans [51].

Apparatus used for COPD induction. Validated and scientifically-sound apparatus is one of the most important parts of the project for animal studies concerning chronic disease. The exposure of animals can be carried out in a smoking apparatus which consists of 4 major parts: power supply (for controlling DC current in circulation fan), a cigarette burn box (metal) with a glass, sliding door (for controlling air supply and handling cigarette), a circulation fan (connected to the cigarette burn box and blows S CS into the inhalation chamber), and an inhalation chamber (for exposing a minimum of 3 rats to sidestream smoke at a time; dimensions: $30 \mathrm{~cm}$ length $\times 20 \mathrm{~cm}$ width $\times 25 \mathrm{~cm}$ height). The smoke concentration in the chamber can be controlled by an air control hole and smoke burning speed, whereas measurement of the concentration of the CS in the chamber CO meter can be performed as it is one of the contents of CS $[52,53]$.

Some studies have also attempted to construct an apparatus that could both fulfill the objective and be affordable, consisting of a compartment containing 2 parts: a containment system and a CS device. The containment system comprised of 4 metal cages, closed at the top, which were made to accommodate 4 rats or 16 mice in each cage, and the metal cages contained inside one big acrylic box. The CS device consisted of an external cigarette holder joined to a suction pump. The pump generated a negative pressure which easily helped in the generation of smoke from cigarettes in exactly the way humans smoke cigarettes - by suction [34].

In a similar study, the rats were kept in an apparatus consisting of a ventilator, a smoke-generating chamber, and a whole-body CSE chamber connected serially via silicone tubes interlined by Heimlich valves (Becton Dickin-son, Franklin Lakes, NJ, USA) to avoid smoke regression. The ventilator (Veterinary Anaesthesia Ventilator Model 2000, Hallowell EMC, Pittsfield, MA, USA) supplied $150 \mathrm{~mL}$ of air every 10s. An acrylic cylinder (radius, diameter $8 \mathrm{~cm}$; height, $27 \mathrm{~cm}$ ), total volume $5,430 \mathrm{~cm} 3$, was included in the smokegenerating chamber where one cigarette was constantly lit. Smoke was then delivered to an acrylic white chamber (length, $40 \mathrm{~cm}$; width, $20 \mathrm{~cm}$; height, $25 \mathrm{~cm}$ ), total volume $20,000 \mathrm{~cm} 3$, and exhausted through a hole [54].

Another customized apparatus consisted mainly of a peristaltic pump for supplying $150 \mathrm{ml}$ of air every $10 \mathrm{~s}$, a CS generation chamber $(27 \mathrm{~cm} \times 16 \mathrm{~cm})$ to keep a cigarette burning, and a Whole-body CS exposure chamber $(40 \mathrm{~cm}$ $\times 20 \mathrm{~cm} \times 25 \mathrm{~cm})$ in which the animals were kept. All these chambers were connected serially by silicone tubes, and were custom made for SCS exposure. The concentration of CO was measured using a $\mathrm{CO}$ meter [55].

The advantage of the assembled apparatus is that it can be made according to the requirements of an experiment, but the disadvantage is the cost. Moreover, commercially available instruments are also available, such as cigarette smoking machine Borgwaldt-KC condor Sm85, BUXCO animal CS-exposure system (DSI, USA), which can provide CS equivalent to 20 cigarettes.

\section{CONCLUSION}

COPD is a life-threatening inflammatory disease. It is world known fact that it causes chronic morbidity and death worldwide and that CS is a significant contributing factor; its prevalence is also increasing and is the fourth leading cause of morbidity around the globe. The effect of CS is observed in the form of chronic airway inflammation, mucus hypersecretion, airway remodelling, and emphysema, which lead to reduced lung function and breathlessness $[54,55]$. The study of COPD is hampered primarily by the lack of development of small animal models. It was observed that guinea pigs, due to their anatomical similarity, are a better model that can be used to develop COPD. Similarly, the combination of SCS/ MCS with LPS should be preferred over the single smoke component to induce COPD. It was observed that mouse models are extensively used over rats, the females are more vulnerable to COPD and exhibit a significant degree of lung deterioration with a specific amount of tobacco smoking [56, 57]. Among female mice, C57B1/6 mice, and $\mathrm{BALB} / \mathrm{c}$ mice are preferred, whereas, in rat models, male SD rats are mostly used. Conventionally authenticated researchgrade cigarettes should be used for effortless distribution of a specific concentration of TSP or TPM, including nicotine and carbon monoxide. Pathomorphological indicators should be considered to be of paramount importance for evaluating the establishment of the animal model [57]. Moreover, the types of apparatus to be used is a perquisite for COPD induction in murine models, taking into consideration optimum exposure and reliability, as well as the sturdiness of the apparatus which would provide better execution of the protocol with minimum harm to the experimenter animals used.

\section{Conflict of interest statement}

The authors declare that there are no conflicts of interest.

\section{Declaration}

This research received no specific grant from any funding agency in the public, commercial, or not-for-profit sectors

\section{REFERENCES}

1.Eapen, MS, Hansbro, P.M, Larsson-Callerfelt, AK, Jolly MK, Myers S, Sharma P, Jones B, Rahman MA, Markos J, Chia C, Larby J, Haug G, Hardikar A, Weber HC, Mabeza G, Cavalheri V, Khor YH, McDonald CF, Sohal SS. Chronic Obstructive Pulmonary Disease, and Lung 
Cancer: Underlying Pathophysiology and New Therapeutic Modalities. Drugs 2018; 78(16): 1717-1740.

2. Uemasu K, Tanabe N, Tanimura K, Hasegawa K, Mizutani T, Hamakawa Y, Sato S, Ogawa E, Thomas MJ, Ikegami M, Muro S, Hirai T, Sato A. Serine Protease Imbalance in the Small Airways and Development of Centrilobular Emphysema in Chronic Obstructive Pulmonary Disease Serine Protease Imbalance in the Small Airways and Development of Centrilobular Emphysema in Chronic Obstructive Pulmonary Disease. Am J Respir Cell Mol Biol 2020; 63(1): 67-78.

3. Pandey KC, De S, Mishra PK. Role of Proteases in Chronic Obstructive Pulmonary Disease. Front Pharmacol 2017; 8: 1-9.

4. Thimmulappa RK, Chattopadhyay I, Rajasekaran S. Oxidative Stress Mechanisms in the Pathogenesis of Environmental Lung Diseases. Oxidative Stress in Lung Diseases. 2019; 103-137.

5.Zhou A, Luo L, Liu N, Zhang C, Chen Y, Yin Y, Zhang J, He Z, Xie L, Xie J, Li J, Zhou Z, Chen Y, Chen P. Prospective development of practical screening strategies for diagnosis of asthma - COPD overlap. Respirology 2020; 25(7): 735-742.

6. Sim YS, Lee JH, Lee WY, Suh DI, Oh YM, Yoon JS, Lee JH, Cho JH, Kwon CS, Chang JH. Tuberc Respir Dis (Seoul) 2017; 80(2): 105-112.

7. da Costa CH, Noronha Filho AJ, Marques E Silva RMF, da Cruz TF, de Oliveira Monteiro V, Pio M, Rufino RL. Alpha 1-antitrypsin deficiency in patients with chronic obstructive pulmonary disease patients: Is systematic screening necessary? BMC Res Notes. 2019; 12(10): $1-5$.

8. Andarian SJ, Olyaeemanesh A, Hosseini SA, Sari AA, Firoozbakhsh S, Jadesi MN, Mobinizadeh M. The safety and effectiveness of the current treatment regimen with or without roflumilast in advanced COPD patients: A systematic review and meta-analysis of randomized controlled trials. Med J Islam Repub Iran. 2016; 30(1): 332.

9. Roche N. Stable COPD Treatment: Where are We?, COPD: Journal of Chronic Obstructive Pulmonary Disease. 2018; 15(2): 123-129.

10. Celli BR, Anderson JA, Cowans NJ, Crim C, Hartley BF, Martinez FJ, Morris AN, Quasny H, Yates J, Vestbo J, Calverley PMA. Pharmacotherapy and Lung Function Decline in Patients with Chronic Obstructive Pulmonary Disease. A Systematic Review. Am J Respir Crit Care Med 2021 Mar 15; 203(6): 689-698.

11. Hough KP, Curtiss ML, Blain TJ, Liu R-M, Trevor J, Deshane JS and Thannickal VJ Airway Remodeling in Asthma. FrontMed. 2020; 7: 191

12. Sidletskaya K, Vitkina T, Denisenko Y. The role of toll-like receptors 2 and 4 in the pathogenesis of the chronic obstructive pulmonary disease. Int J COPD. 2020; 15: 1481-1493.

13. Lannoy V, Côté-Biron A, Asselin C, Rivard N. Phosphatases in toll-like receptors signaling: the unfairly-forgotten. Cell Commun Signal. 2021; 19(1): 10.

14. Rodríguez-Arce I, Morales X, Ariz M, Euba B, López-López N, Esparza M, Hood DW, Leiva J, Ortíz-de-Solórzano C, Garmendia J. Development and multimodal characterization of an elastase-induced emphysema mouse disease model for the COPD frequent bacterial exacerbator phenotype. Virulence. 2021; 12(1): 1672-1688.

15. Hewitt R, Farne H, Ritchie A, Luke E, Johnston SL, Mallia P. The role of viral infections in exacerbations of chronic obstructive pulmonary disease and asthma. Ther Adv Respir Dis. 2016 Apr; 10(2): 158-74.

16. Chapman KR. Bench to Bedside and Back: The Evolving Story of Alpha-1 Antitrypsin Deficiency. Am J Respir Cell Mol Biol 2021; 63(4): 403-404.

17. Carver PI, Anguiano V, D’Armiento JM, Shiomi T. Mmpla, and Mmplb are not functional orthologs to human MMP1 in cigarette smokeinduced lung disease. Exp Toxicol Pathol. 2015 Feb; 67(2): 153-9.

18. Pinkerton KE, Van Winkle LS, Plopper CG, Smiley-Jewell S, Covarrubias EC, McBride JT. Architecture of the tracheobronchial tree. Comp Biol Norm Lung. 2015; 2: 33-51.

19. Ramírez-Ramírez E, Torres-Ramírez A, Alquicira-Mireles J, Cañavera-Constantino A, Segura-Medina P, Montaño-Ramírez M, Ramos-Abraham C, Vargas MH, Arreola-Ramírez JL. Characteristic plethysmographic findings in a guinea pig model of COPD. Exp Lung Res 2017; 43(2): 57-65.

20. Plopper CG, Hyde DM. Epithelial Cells of the Bronchiole. 2nd ed. Parent RA, editor. Comparative Biology of the Normal Lung. Academic Press; 2015. p. 83-92.

21. Gehrig S, Duerr J, Weitnauer M, Wagner CJ, Graeber SY, Schatterny J, Hirtz S, Belaaouaj A, Dalpke AH, Schultz C, Mall MA. Lack of neutrophil elastase reduces inflammation, mucus hypersecretion, and emphysema, but not mucus obstruction, in mice with cystic fibrosis-like lung disease. Am J Respir Crit Care Med. 2014 May 1; 189(9): 1082-92.

22. Horinouchi T, Higashi T, Mazaki Y, Miwa S. Carbonyl Compounds in the Gas Phase of Cigarette Mainstream Smoke and Their Pharmacological Properties. Biol Pharm Bull. 2016; 39(6): 909-14.
23. Ghorani V, Boskabady MH, Khazdair MR, Kianmeher M. Experimental animal models for COPD: a methodological review. Tob Induc Dis 2017; 15(25): 1-13.

24. Reczyńska K, Tharkar P, Kim SY, Wang Y, Pamuła E, Chan HK, Chrzanowski W. Animal models of smoke inhalation injury and related acute and chronic lung diseases. Adv Drug Deliv Rev. 2018; 123: 107-134.

25. Mohammad Y, Shaaban R, Al-Zahab BA, Khaltaev N, Bousquet J, Dubaybo B. Impact of active and passive smoking as risk factors for asthma and COPD in women presenting to primary care in Syria: first report by the WHO-GARD survey group. Int J Chron Obstruct Pulmon Dis. 2013; 8: 473-82.

26. Wang G, Mohammadtursun N, Lv Y, Zhang H, Sun J, Dong J. Baicalin exerts anti-airway inflammation and anti-remodeling effects in the severe stage rat model of chronic obstructive pulmonary disease. Evid. 2018; 1: 1-14.

27. Wang G, Mohammadtursun N, Sun J, Lv Y, Jin H, Lin J, Kong L, Zhao Z, Zhang H, Dong J. Establishment and evaluation of a rat model of sidestream cigarette smoke-induced chronic obstructive pulmonary disease. Front Physiol 2018; 9: 58.

28. Wang L, Kong CC, Chen YR, Fu DY, Li J, Huang CY, Gan GX, Chen BB, Liang M, Xu M, Hu RC, Tan SX, Dal AG. Effect of Atorvastatin on Lung Apoptosis-Associated Protein Caspase-12 in Chronic Obstructive Pulmonary Disease (COPD) Model Rats. J Anesthesiol Pain Res. 2019; 2(1): $10-13$.

29. Fricker M, Deane A, Hansbro PM. Animal models of chronic obstructive pulmonary disease. Expert Opin Drug Discov. 2014 Jun; 9(6): 629-45.

30. Sun J, Bao J, Shi Y, Zhang B, Yuan L, Li J, Zhang L, Sun M, Zhang L, Sun W. Effect of simvastatin on MMPs and TIMPs in cigarette smokeinduced rat COPD model. Int J COPD 2017; 12: 717-724.

31. Scott A, Lugg ST, Aldridge K, et al. Pro-inflammatory effects of e-cigarette vapour condensate on human alveolar macrophages. Thorax. 2018; 73: 1161-1169.

32. Caia GL, Efimova OV, Velayutham M, El-Mahdy MA, Abdelghany TM, Kesselring E, Petryakov S, Sun Z, Samouilov A, Zweier JL. Organspecific mapping of in vivo redox state in control and cigarette smokeexposed mice using EPR/NMR co-imaging. J Magn Reson 2012; 216 : 21-27.

33. Pan X, Xu K, Li Y, Wang X, Peng X, Li M, Li Y. Interleukin-35 expression protects against cigarette smoke-induced lung inflammation in mice. Biomed Pharmacother 2019; 110: 727-732.

34. Yang Jinho, Kim Eun Kyoung, Park Hyeon Ju, McDowell Andrea, Kim Yoon-Keun. The impact of bacteria-derived ultrafine dust particles on pulmonary diseases. Virulence. 2021; 2(1): 1672-1688.

35.Li C, Yan Y, Shi Q, Kong Y, Gao L, Bao H, Li Y. Recuperating lung decoction attenuates inflammation and oxidation in cigarette smokeinduced COPD in rats via activation of ERK and Nrf2 pathways. Cell Biochem Funct 2017; 35(5): 278-86.

36. Miao L, Gao Z, Huang F, et al. Erythromycin enhances the antiinflammatory activity of budesonide in COPD rat model. Int J Clin Exp Med 2015; 8(12): 22217-22226.

37. Weng J, Wang Y, Sun TY. Cathelicidin LL-37 restoring glucocorticoid function in smoking and lipopolysaccharide-induced airway inflammation in rats. Chin Med J. 2019; 132(5): 1-8.

38. Miao L, Gao Z, Huang F, Huang S, Zhang R, Ma D, Wu Q, Li F, Chen H, Wang J. Pulmonary Pharmacology \& Therapeutics Characteristic comparison of three rat models induced by cigarette smoke or combined with LPS: To establish a suitable model for the study of airway mucus hypersecretion in chronic obstructive pulmonary disease. Pulm Pharmacol Ther 2012; 25: 349-356.

39. Wang XL, Li T, Li JH, Miao SY, Xiao XZ. The Effects of Resveratrol on Inflammation and Oxidative Stress in a Rat Model of Chronic Obstructive Pulmonary Disease longevity. Molecules 2017; 22(9): 1529.

40.Zhang XF, Zhu J, Geng WY, Zhao SJ, Jiang CW, Cai SR, Cheng M, Zhou CY, Liu ZB. Electroacupuncture at Feishu (BL13) and Zusanli (ST36) down-regulates the expression of orexins and their receptors in rats with chronic obstructive pulmonary disease. J Integr Med. 2014; 12(5): 417-424.

41. Lee JW, Ryu HW, Park SY, Park HA, Kwon OK, Yuk HJ, Shrestha KK, Park M, Kim JH, Lee S, Oh SR, Ahn KS. Protective effects of neem (Azadirachta indica A. Juss.) leaf extract against cigarette smoke- and lipopolysaccharide-induced pulmonary inflammation. Int J Mol Med. 2017 Dec; 40(6): 1932-1940.

42. Yang Y, Di T, Zhang Z, et al. Dynamic evolution of emphysema and airway remodeling in two mouse models of COPD. BMC Pulm Med. 2021; 21: 134.

43. Lee JW, Ryu HW, Lee SU, Kim MG, Kwon OK, Kim MO, Oh TK, Lee JK, Kim TY, Lee SW, Choi S, Li WY, Ahn KS, Oh SR. Pistacia 
weinmannifolia ameliorates cigarette smoke and lipopolysaccharideinduced pulmonary inflammation by inhibiting interleukin- 8 production and NF-kB activation. Int J Mol Med. 2019; 44(3): 949-959.

44. Cafferkey J, Coultas JA, Mallia P. Human rhinovirus infection and COPD: role in exacerbations and potential for therapeutic targets. Expert Rev Respir Med. 2020; 1-13.

45. Wen wen. Expression of connective tissue growth factor and bone morphogenetic protein-7 in Pseudomonas aeruginosa-induced chronic obstructive pulmonary disease in rats. COPD. 2013; 10(6): 657-666.

46. Foronjy RF, Dabo AJ, Taggart CC, Weldon S, Geraghty P. Respiratory syncytial virus infections enhance cigarette smoke-induced COPD in mice. PLoS One. 2014; 9(2): 90567.

47. Kozma Rde L, Alves EM, Barbosa-de-Oliveira VA, Lopes FD, Guardia RC, Buzo HV, Faria CA, Yamashita C, Cavazzana Júnior M, Fre F, Ribeiro-Paes MJ, Ribeiro-Paes JT. A new experimental model of cigarette smoke-induced emphysema in Wistar rats. JBP. 2014; 40(1): 46-54.

48. Ke Q, Yang L, Cui Q, et al. Ciprofibrate attenuates airway remodeling in cigarette smoke-exposed rats. Respir Physiol Neurobiol. 2020; 271: 1-9.

49. Wang L, Meng J, Wang C, Yang C, Wang Y, Li Y, Li Y. Highlight article: Hydrogen sulfide alleviates cigarette smoke-induced COPD through inhibition of the TGF- $\beta 1 /$ smad pathway. Exp Biol Med. 2020; 245(3): 190-200.

50. Luo F, Liu J, Yan T, Miao M. Salidroside alleviates cigarette smokeinduced COPD in mice. Biomed Pharmacother 2017; 86: 155-161.
51. Yu D, Liu X, Zhang G, Ming Z, Wang T. Isoliquiritigenin inhibits cigarette smoke-induced COPD by attenuating inflammation and oxidative stress via the regulation of the Nrf2 and NF- $\kappa \mathrm{B}$ signaling pathways. Front Pharmacol 2018; 9: 1-8.

52. Nie YC, Wu H, Li PB, Luo YL, Long K, Xie LM, Shen JG, Su WW. J Med Food. 2012; 15: 894-900.

53. Li Y, Gu C, Xu W, Yan J, Xia Y, Ma Y, Chen C, He X, Tao H. Therapeutic effects of amniotic fluid-derived mesenchymal stromal cells on lung injury in rats with emphysema. Respir Res. 2014; 15: 1-14.

54. Possebon L, de Souza Lima Lebron I, Furlan da Silva L, Tagliaferri Paletta J, Glad BG, Sant'Ana M, Iyomasa-Pilon MM, Ribeiro Souza H, de Souza Costa S, Pereira da Silva Rodriguesa G, Pereira ML, de Haro Moreno A, Girol AP. Anti-inflammatory actions of herbal medicines in a model of chronic obstructive pulmonary disease induced by cigarette smoke. Biomed Pharmacother. 2018; 99: 591-597.

55. Dianat M, Radan M, Badavi M, Mard SA, Bayati V, Ahmadizadeh M. Crocin attenuates cigarette smoke-induced lung injury and cardiac dysfunction by anti-oxidative effects: the role of Nrf2 antioxidant system in preventing oxidative stress. Respiratory research. 2018; 19(1): 58.

56. Shen Y, Huang S, Kang J, Lin J, Lai K, Sun Y, Xiao W, Yang L, Yao W, Cai S, Huang K, Wen F. Management of airway mucus hypersecretion in chronic airway inflammatory disease: Chinese expert consensus (English edition). Int J Chron Obstruct Pulmon Dis. 2018; 13: 399-407. 57. Liang G-B, He Z-H. Animal models of emphysema. Chin Med. 2019; 132(20): 2465-2475. 